\title{
Lithium-Ion Battery Thermal Management Systems: A Survey and New CFD Results
}

\author{
Morena Falcone ${ }^{1} \mathbb{D}$, Eleonora Palka Bayard De Volo ${ }^{1}$, Ali Hellany ${ }^{2}$, Claudio Rossi ${ }^{3}$ and Beatrice Pulvirenti ${ }^{1, * \mathbb{D}}$ \\ 1 Department of Industrial Engineering, Alma Mater Studiorum Università di Bologna, Viale Risorgimento 2, \\ 40136 Bologna, Italy; morena.falcone@unibo.it (M.F.); eleonora.palkabayar2@unibo.it (E.P.B.D.V.) \\ 2 School of Engineering, Design and Built Environment, University of Western Sydney, \\ Penrith, NSW 2751, Australia; A.Hellany@westernsydney.edu.au \\ 3 Department of Electric Energy Engineering, Alma Mater Studiorum Università di Bologna, \\ Viale Risorgimento 2, 40136 Bologna, Italy; claudio.rossi@unibo.it \\ * Correspondence: beatrice.pulvirenti@unibo.it
}

Citation: Falcone, M.; Palka Bayard De Volo, E.; Hellany, A.; Rossi, C.; Pulvirenti, B. Lithium-Ion Battery Thermal Management Systems: A Survey and New CFD Results. Batteries 2021, 7, 86. https://doi.org/ $10.3390 /$ batteries7040086

Academic Editors: Seung-Wan Song, Kai Peter Birke and Duygu Karabelli

Received: 4 August 2021

Accepted: 8 December 2021

Published: 14 December 2021

Publisher's Note: MDPI stays neutral with regard to jurisdictional claims in published maps and institutional affiliations.

Copyright: (c) 2021 by the authors. Licensee MDPI, Basel, Switzerland. This article is an open access article distributed under the terms and conditions of the Creative Commons Attribution (CC BY) license (https:// creativecommons.org/licenses/by/ $4.0 /)$.

\begin{abstract}
The environment has gained significant importance in recent years, and companies involved in several technology fields are moving in the direction of eco-friendly solutions. One of the most discussed topics in the automotive field is lithium-ion battery packs for electric vehicles and their battery thermal management systems (BTMSs). This work aims to show the most used lithium-ion battery pack cooling methods and technologies with best working temperature ranges together with the best performances. Different cooling methods are presented and discussed, with a focus on the comparison between air-cooling systems and liquid-cooling systems. In this context, a BTMS for cylindrical cells is presented, where the cells are arranged in staggered lines embedded in a solid structure and cooled through forced convection within channels. The thermal behavior of this BTMS is simulated by employing a computational fluid dynamics (CFD) approach. The effect of the geometry of the BTMS on the cell temperature distribution is obtained. It is shown that the use of materials with additives for the solid structure enhances the performance of the system, giving lower temperatures to the cells. The system is tested with air-cooling and water-cooling, showing that the best performances are obtained with water-cooling in terms of cell packing density and lowest cell temperatures.
\end{abstract}

Keywords: lithium-ion cells; battery thermal management systems; CFD simulations; liquid cooling

\section{Introduction}

Driven by the need to lower the pollution at street level, the interest in electric vehicles is growing increasingly. Lithium-ion cells are the most commonly used batteries in electric vehicles (EVs) due to their high power density ( $255 \mathrm{Wh} / \mathrm{kg}$ for commercial products, and, in the short term, cells with $270 \mathrm{Wh} / \mathrm{kg}$ are expected on the market), low self-discharge rate, high recyclability, light weight and compact size, which is very helpful when space is lacking. They also have a longer life cycle with respect to the other rechargeable batteries [1-3]. On the other hand, Li-ion cells show highly non-isotropic thermal properties due to the different layers of the electrodes [4]. In addition, the automotive field necessity of having compact battery packs leads to modules with small space among the cells and between the strings. This yields high temperatures and non-uniform thermal distribution situations, which make the battery efficiency worse and can cause them to degenerate in dangerous and uncontrolled environments. For instance, thermal runaway is caused by successive processes that can lead to fire and combustion [5]. Today, 18,650 Li-ion cells (with diameter $18 \mathrm{~mm}$ and length $65 \mathrm{~mm}$ ) are among the most used batteries in the automotive field because of their small size: as the cells contain a limited amount of energy, if a failure event occurs, the effect is much less than that expected from a larger cell [6]. These cells were introduced by Tesla more than ten years ago on the pioneer Roadster model, and now they 
are massively used in the 21,700 format on Tesla Model X and Model 3. Recent diffusion of cylindrical cells in realizing large packs are mainly driven by the exploitation of simple integration technology, allowing the realization of modules containing between 50 and 100 cells in parallel. Many efforts have been made to increase the battery efficiency. Research in this area started with investigations about why Li-ion batteries should have represented the best choice for EVs [7], then proceeded with a considerable number of simulations (for example, Huang et al. used 3D simulations to study the convection in the spacing between the cells and what their best arrangement is [8]). The final step was the validation of the simulations (for instance, experiments about the effects of different arrangements and shapes of the cells [9-11]). In the context of battery pack cooling management, it is necessary to take into consideration several methods and systems to control the temperature of a battery pack, maintaining it in a precise range. In this work, battery thermal management systems (BTMSs) are considered. Many approaches are involved in various aspects of BTMSs: air cooling, hydrogen cooling, helium cooling, ammonia cooling, liquid cooling, phase change materials [12,13], and hybrid cooling, all used to reduce energy waste and to achieve the battery best performances. Each method has its own pros and cons and is more suitable for a precise application rather than another. The best operating temperature range for Li-ion batteries is between $15^{\circ} \mathrm{C}$ and $40^{\circ} \mathrm{C}$, as suggested by many recent studies [14]. If the temperature rises above $50^{\circ} \mathrm{C}$, the charging efficiency and the longevity of batteries decreases [15]. The purpose of a BTMS is to keep the cell temperature within the optimal range while maintaining the temperature's uniformity within the modules [16]; heating is also essential in those rare situations when the battery temperature is lower than the minimum acceptable temperature. At low temperatures, discharging of a charged Li-ion battery is easier than charging of a discharged one [17], and the capacity of Li-ion batteries can decrease up to $95 \%$ when the Energy Storage System (ESS) is operating at $-10{ }^{\circ} \mathrm{C}$ [18]. Due to the exothermic nature of the chemical reactions inside the batteries, few studies have been done about heating [19]. However, there are some promising studies about internal self-heating strategies to overcome the poor performances at low temperatures [20] and the reduction of battery life [21]. While studying the heat dissipation performances of a battery pack, two main indexes are usually taken into account: the maximum temperature increase $\left(T_{r i s, \max }\right)$ and the maximum temperature difference $\left(T_{\text {dif,max }}\right)$. The maximum temperature rising is the maximum difference value between the battery pack temperature and the environmental temperature. The maximum temperature difference is the maximum difference value recorded inside the battery pack. If $T_{r i s, \max }$ is too high, it means that the environmental temperature is relatively low for the battery pack and that it is not possible to remove the heat generated by the battery pack through the cooling system. If $T_{\text {dif, max }}$ is too high, it means that there is no uniform temperature distribution inside the battery pack. An appropriate cooling system design is necessary to reduce both $T_{r i s, \max }$ and $T_{d i f, \max }$. It is desirable to have the maximum temperature increase be less than $10^{\circ} \mathrm{C}$ and the maximum temperature difference be less than $5^{\circ} \mathrm{C}$ [22]. Concerning air-cooling methods, ref. [23], Zhou et al. [16] show the advantages of an air distribution pipe thermal manage system, and $\mathrm{Xu}$ et al. [22] studied the optimization of the forced air cooling, testing the effects of different airflow duct modes; indeed, Xie et al. [24] do so by modifying factors such as the air inlet-angle and the outlet-angle. There are also studies that propose a multi-parameter control strategy for air-based BTMSs [25] to monitor the state of health $(\mathrm{SOH})$ of the battery and energy consumption in function of the temperature fluctuations and the air mass-flow rates. Many experiments have been carried out on not only to optimize the whole BTMS, but also to analyze the thermal conditions inside the single battery modules improving the temperature uniformity. Several methods have been explored, with analytical and experimental tests, such as the installation of a baffle plate [26], different cell arrangement structures [10], the spacing optimization between the battery cells [27], and the installation of a secondary vent [28] in an air-cooled BTMS. Other examples are the addition of an inlet plenum [29], special axial-flow air-cooling systems [30], nanofluid-based cooling techniques with forced air-flow to remove the heat from the battery arrangement [31]. Among 
all the liquid cooling BTMSs, the cooling plates are those on which it has been written less considering to cool the cylindrical 18650 lithium-ion batteries often used in the automotive field. Several studies have been carried on about prismatic cells cooled by cooling plates, about how this system can be designed [32], improved, and optimized [33], focusing on which parameters more influence the optimum working point. Recently, some studies [34] have shown that it makes sense to compare cylindrical cells to much larger prismatic ones. This is first because the governing chemistry reactions inside both kinds of the batteries are the same. Secondly, it has to be assumed that the experiments are performed with strict temperature control, which means considering an extensive thermal mass test system with exceptional temperature control sensors. Cooling plates were shown to be a good solution in particular for those applications where high thermal conductivity and compact design are required. This is why they are a common choice in the automotive field. An advanced liquid cooling system can involve the use of heat pipes [35,36], leading to energy saving in electric vehicles, with better BTMS performances and increasing heat flux loads [37]. In particular, recent studies have explored heat pipes used in innovative systems such as inclined U-shaped flat micro heat pipes [38] and hybrid oscillating heat pipes (OHPs) with an ethanol aqueous solutions of carbon nanotubes as working fluid [39]. Other innovative studies have focused their attention on the thermal performance achievable using a two-phase refrigerant BTMS, comparing it with an ordinary liquid cooled one [40]. The thermal performances of liquid-based BTMSs coupled with heat-pump air-conditioning systems (HPACSs) were investigated by Tang et al. [41] to predict the cooling capability of the liquid system on a basis of a machine learning method. Hydrogen-based cooling systems were realized by Alzareer et al. [42] to maximize the BTMS cooling efficiency in hybrid fuel cell electric vehicles (HEVs) with prismatic battery packs. These systems are also able to increase the driving range of these vehicles in which the hydrogen is used both as coolant in aluminum cold plates and as fuel. Among the HEV BTMSs, Alipour et al. [43] studied the cooling capability of a helium-based cooling system (suitable for EVs as well) on pouch cells, comparing it with an ordinary air-based BTMS and optimizing its efficiency in function of several factors such as the inlet flow rate (the most influential one), the flow direction, and the inlet and outlet diameters. Ammonia is also considered as a refrigerant to cool the future HEV batteries: Al-Zareer et al. [44] create an electrochemical thermal model to study an innovative semi-immersive ammonia-based system for cylindrical cells. The system exploits the ammonia boiling process that involves the parts of the batteries immersed into the coolant, and then the natural convection process when the ammonia vapor cools the part of the cells out from the ammonia pool. Recently, hybrid BTMSs that combine natural air convection with liquid and thermoelectric cooling systems (TEC) have been introduced [45], together with innovative cooling methods such as the adoption of liquid immersive solutions by TESLA: these systems perform well both in hot and in cold environments [46]. Finally, a panoramic view of several emergency strategies needed to prevent the thermal runaway (TR) is given. The inception of TR is generally a consequence of an internal short circuit (ISC) inside a single cell that is caused by either mechanical or electrical abuse. It is important in that case to lower the damages or, in the worst cases, to extinguish fire [47-49]. This paper aims to give an overview of the different approaches for thermal management of lithium battery packs. In this context, a BTMS for cylindrical cells is presented, where the cells are arranged in staggered lines and embedded in a solid structure between wavy channels. A Computational Fluid Dynamics (CFD) approach is presented to simulate the thermal behavior of battery cells and to optimize the distance between the cells and the width of the channels with different materials used for the cells support and with different cooling fluids. The arrangement shown in this work is novel, both for the characteristics of the solid material in which the cells are embedded and for the coupling between thermal conduction and convective cooling methods adopted. Moreover, the CFD-based optimization approach to find the best performances of the BTMS is original and shows interesting results for a cells arrangement typical for automotive and that can be easily generalized. The temperature distribution on the cells is obtained with very high 
heat loads. The optimal coolant conditions that give the best thermal performances for the arrangement of the cells are obtained. It is shown that the use of materials with additives to increase the thermal conductivity enhances the heat overall heat transfer for this type of BTMS and gives lower temperatures of the cells. The best performances are obtained by using water instead of air, with small channel widths and with an optimal distance between cells in the direction parallel to the flow.

\section{A Survey of the Battery Thermal Management Systems}

In this section, some aspects concerning battery cooling with a focus on innovative systems are described. A comparison between some air-cooling technologies and liquidcooling systems is introduced.

\subsection{Air Cooling-Prismatic Cells}

One of the easiest ways to control the battery pack temperature is by utilizing aircooling systems. These can be realized with natural ventilation or with forced ventilation. Several simulations and experimental tests are available in the literature, which evidence the effect of different airflow duct modes [22] or important construction details such as the air-inlet angle, the air-outlet angle, and the width of the airflow channel between battery cells [16]. Many studies deal with the temperature distribution and streamlines obtained in different arrangements of the air-flow for battery pack made with densely packed prismatic cells.

Interesting results can be extrapolated from the research of $\mathrm{Xu}$ et al. [22]. In a parallel flow arrangement, the air flows parallel to the battery cells and is expelled by the fans from the air-outlets. The highest temperature areas are inside the battery near the air-outlet. With this configuration, the heat dissipation performance requirements are not satisfied with any of the environmental temperatures considered $\left(T_{\text {env }, 1}=20^{\circ} \mathrm{C}, T_{\text {env, } 2}=27^{\circ} \mathrm{C}\right.$, $T_{\text {env }, 3}=40^{\circ} \mathrm{C}$ ).

In a cross-flow arrangement, the air flows perpendicularly to the battery cells and the shorter air-flow paths improve the heat dissipation. The temperature peaks are lower, showing that this configuration is better than a parallel-flow one in terms of heat dissipation. Mixed approaches, such as adding double-passage or U-passage channels at the bottom of the battery pack, can increase the heat transfer performances. Using the double-passage channel, the temperature values are lower with respect to the previous tests but not enough to satisfy the heat dissipation performance requirements for all the environmental temperatures considered (only for $27^{\circ} \mathrm{C}$ and $40^{\circ} \mathrm{C}$ ). In the last case of a bottom U-passage, it clearly appears that the temperature field distribution is more uniform with respect to the double passage. Using the U-passage, the temperatures are lower with respect to all the previous cases, satisfying the heat dissipation performance requirements for all the environmental temperatures considered (the value of $T_{\text {ris, max }}=10.10^{\circ} \mathrm{C}$ for $T_{\text {env }}=20^{\circ} \mathrm{C}$ is sufficiently close to the specification). In Table 1 , the values of $T_{\text {ris, } \max }(\mathrm{A})$ and $T_{\text {dif, } \max }(\mathrm{B})$ in the parallel flow test are compared with those recorded during the other tests in terms of temperature decreasing.

With the U-passage, the heat dissipation requirements are satisfied for $\mathrm{SOC}=70 \%$ and SOC $=100 \%$, but the results are better for the lowest SOC percentage: this means that in case of insufficient heat dissipation condition, it could be helpful to work with lower SOC values [22]. The heat dissipation requirements are satisfied for the charge and discharge rates of $0.6 \mathrm{C}, 0.8 \mathrm{C}$ and $1 \mathrm{C}$ with the best results for the lowest of these values: this means that, in the case of insufficient heat dissipation condition, it could be helpful to work with lesser charge and discharge rates [22]. The angle between air-inlet and air-outlet channels and the battery cells, as well as the air-flow channel width, are crucial for different aspects. Xie et al. [24] focus their attention on these aspects of prismatic lithium-ion cells arrangements. The environmental temperature for the experimental tests is set at $25^{\circ} \mathrm{C}$. During the tests, the air-inlet angle and the air-outlet angle are changed on the basis of the size of the inlet and outlet channels, respectively, while the layout of the air-flow channels is 
changed by the gap in the battery pack. Another important factor considered is the distance between the cells [24]. By taking into account all these parameters, the lowest values of $T_{\text {ris,max }}$ and $T_{\text {dif,max }}$ are obtained for the cases of the air-inlet angle of $2.5^{\circ}$ and air-outlet angle of $2.5^{\circ}$, with evenly-spaced air flow channel between battery cells. The values of $T_{\text {ris,max }}$ and $T_{\text {dif,max }}$ are dropped by $12.82 \%$ and $29.72 \%$, respectively, by the optimization approach [24].

Table 1. Temperature decreasing obtained moving from a parallel flow cooling method to a U-passage technology at different environmental temperatures [22].

\begin{tabular}{|c|c|c|c|c|}
\hline & Environmental Temperature $\left({ }^{\circ} \mathrm{C}\right)$ & 20 & 27 & 40 \\
\hline \multirow[t]{2}{*}{ Parallel flow } & Maximum temperature rise $\left({ }^{\circ} \mathrm{C}\right)$ & $\mathrm{A}_{20}$ & $\mathrm{~A}_{27}$ & $\mathrm{~A}_{40}$ \\
\hline & Maximum temperature difference $\left({ }^{\circ} \mathrm{C}\right)$ & $\mathrm{B}_{20}$ & $\mathrm{~B}_{27}$ & $\mathrm{~B}_{40}$ \\
\hline \multirow[t]{2}{*}{ Cross-flow } & Maximum temperature rise $\left({ }^{\circ} \mathrm{C}\right)$ & $-2.25 \%$ & $-1.98 \%$ & $-1.50 \%$ \\
\hline & Maximum temperature difference $\left({ }^{\circ} \mathrm{C}\right)$ & $-7.91 \%$ & $-7.27 \%$ & $-5.75 \%$ \\
\hline \multirow[t]{2}{*}{ Double passage } & Maximum temperature rise $\left({ }^{\circ} \mathrm{C}\right)$ & $-36.80 \%$ & $-37.04 \%$ & $-37.55 \%$ \\
\hline & Maximum temperature difference $\left({ }^{\circ} \mathrm{C}\right)$ & $-63.83 \%$ & $-63.84 \%$ & $63.87 \%$ \\
\hline \multirow[t]{2}{*}{ U-passage } & Maximum temperature rise $\left({ }^{\circ} \mathrm{C}\right)$ & $-38.38 \%$ & $-39.03 \%$ & $-38.97 \%$ \\
\hline & Maximum temperature difference $\left({ }^{\circ} \mathrm{C}\right)$ & $-72.58 \%$ & $-73.03 \%$ & $-72.15 \%$ \\
\hline
\end{tabular}

\section{Air Cooling-Cylindrical Cells}

In this section, some air-cooling techniques tested on cylindrical-cell bricks are described. Zhou et al. [16] take into account 18,650 Li-ion batteries, monitoring the temperature of every single cell with k-type thermocouples in three different points: the top, the middle, and the bottom. The air distribution pipes have orifices arranged all along with the axial direction of the pipes themselves. Three kinds of pipes are tested: the first one presents three orifices with $1 \mathrm{~mm}$ diameter, the second one has four orifices with $15 \mathrm{~mm}$ diameter, and the third pipe has five orifices with $2 \mathrm{~mm}$ diameter. The air enters into the pipes from their inlets and flows out from the orifices. Considering a constant discharge rate process, it is shown that the temperature increases from the negative pole to the positive one, and this is explainable with a high battery cap internal resistance (high heating due to the Joule's effect). After this observation, four main factors are considered to optimize the air distribution pipe system: the number and the diameter of the orifices, the air inlet pressure, and the discharge rate. For all the diameters of the orifices, the temperature obtained in the middle of the cells is lower than that on the top and the bottom, and, in particular, it decreases as the orifice diameter increases. This is the effect of an enhanced heat transfer area between the battery surface and the airflow. Choosing pipes with bigger orifices leads to an increase in the forced cooling air inlet area. At the same time, the power consumption increases but it is not a significant effect. The effect of inlet pressure is considered. Higher inlet pressure values lead to higher inlet airflow rates and, consequentially, by increasing the inlet pressure, $T_{\text {dif, max }}$ decreases, while the power consumption increases [16]. As shown by the experiments of $\mathrm{Xu}$ et al. [22] on prismatic cells, the discharge rate affects the temperature. This is because as the heat dissipation rate remains the same, the heat generation rate changes. There is a degree of discharge (DOD) value for each discharge rate from which the temperature starts to drop, but, at the same time, the higher the discharge rate is, the higher the maximum temperature of the battery: the cooling rate declines with the increase of the discharge rate. The maximum temperature difference also increases with the discharge rate. The effect of baffle installation is important. Jiaqiang et al. [26] study the influence of the air-flow inlet and outlet positions and the benefits of a baffle in terms of heat dissipation. The tested module is made of 18,650 Li-ion batteries. The battery cells are $2 \mathrm{~mm}$ spaced from the others, $5 \mathrm{~mm}$ from the case bottom, and $20 \mathrm{~mm}$ from the case top. The inlet airflow speed is $2 \mathrm{~m} / \mathrm{s}$. Figure 1 shows the temperature distribution 
obtained within the brick under different forced ventilation conditions: lateral inlet and outlet, same side, lateral inlet and outlet, opposite side, and a baffle installation.
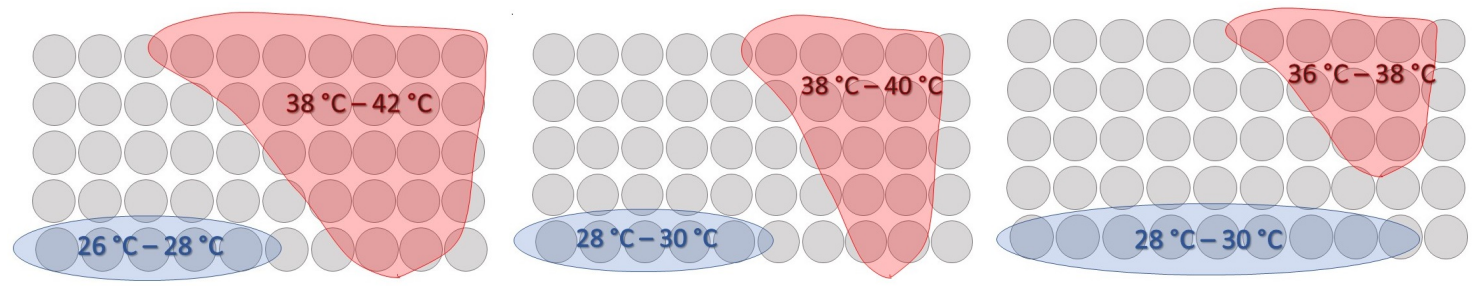

Figure 1. Temperature distribution obtained under different forced-convection conditions obtained in [26]. From left to right: lateral inlet and outlet, same side, lateral inlet and outlet, opposite side, and a baffle installation.

In the first condition, the cells near the air inlet have the lower temperatures, but the highest peaks are obtained on the right, where the inlet air hardly flows through the cells. $T_{r i s, \max }$ and $T_{d i f, \max }$ are still unacceptable. In the second condition, with the inlet and outlet air intakes in these positions, the temperature distribution remains the same, and the higher temperatures obtained before decrease but not enough to consider the values of $T_{r i s, \max }$ and $T_{d i f, \text { max }}$ acceptable. In the third condition, it is possible to narrow and concentrate the airflow with the installation of a simple and cheaper baffle: the result is an improved airflow cooling ability. The temperature distribution is the same as the previous cases without the baffle with optimal working temperature range with $T_{r i s, \max }=38.9^{\circ} \mathrm{C}$. Problems of temperature uniformity still have to be fixed to let the battery work in the optimum temperature range and, at the same time, to satisfy the requirement of $T_{\text {dif, } m a x}<5{ }^{\circ} \mathrm{C}$.

\subsection{Liquid Cooling}

The liquid cooling methods show promising performances thanks to the high thermal conductivity of refrigerant fluids. Indeed, the high weight (including the liquid coolant and the sealing elements to avoid the fluid leakage) and the high manufacturing costs for the fluid coolant circulation system represent some penalties [16], but when high cooling performances are required, air cooling is not sufficient. Here, two leading liquid cooling technologies are presented: cooling plates and heat pipes.

\subsubsection{Cooling Plate Technology}

A typical cooling plate is made of a metal plate on which flow paths are machined. The cooling liquid flows along the flow paths absorbing the cells' heat waste and dissipating it through the plate (by means of conduction and convection heat transfer). The factors that influence the efficiency of this technology are the shape and the size of the flow paths, the available contact surface between the coolant and the flow path walls, the type of coolant, the flow rate, and the material of the plates. Cooling plates can be divided into two categories: the ice plates, which show the best performances and are placed between the battery cells, and the cold plates, which have lower performances but are easier to install because they are placed as a floor under the cells. Ice plates are often preferred in BEVs for their high efficiency, but the tight spaces represent a hard challenge. Darcovich et al. [50] compare the two technologies showing what happens to the maximum cell temperature if we change the cell case material and the coolant. They also take into account two different drive cycles: the US06, an urban-like driving-cycle, and the HWY, for cars which drive along the highways. They also obtain the maximum cell temperature and the battery lifetime as a function of a range of values of $\mathrm{SOH}$. They obtain better temperature uniformity with ice plates than with cold plates. The higher the value of the heat transfer coefficient is, the lower the maximum temperature of the battery is for any kind of cell case materials and driving cycles. This means a longer battery lifetime of about 2 years if we consider US06 driving-cycles, 1 year for HWY driving-cycles. Studies about new technologies suitable to improve cold plates' cooling systems have been done on new kinds of channels such as 
leaf-like channels [51]. The design project provides four collection channels arranged along diagonal lines where the decrease in the temperature gradient is required. After many simulations on the channels analyzing the influence of width and length ratio, as well as channel thickness, and also investigating the optimum inlet mass-flow rate, optimal values of heat dissipation and power consumption have been found. Leaf-like channels can be helpful in the study of fractal networks for cold plates [51].

\subsubsection{Heat Pipes}

Heat pipes (HP) are passive capillary-driven two-phases systems that represent another solution to manage the temperature of electric vehicles battery packs. The two-phase system means that the heat transfer occurs due to a phase change and, in this case, due to the liquid-vapor one. A heat-pipe based cooling system is made of three main parts: the evaporator (heat source), the adiabatic section (which links the first and the third parts and along which the heat transport happens), and the condenser (heat sink). Evaporation and condensation rule the thermodynamic cycle: the coolant within the pipes (usually made of copper) absorbs the heat of the battery cells, which causes the evaporation of the cooling liquid itself, then the fluid moves along the pipes, towards the condenser, with an efficient heat transfer thanks to the latent heat of vaporization. Once the vapor reaches the condenser, another phase change occurs, and it turns to liquid again and heat is dissipated. Simulations [35] have shown that BTM systems based on heat pipes provide energy savings in electric vehicles, keeping the maximum temperature of the battery under $50{ }^{\circ} \mathrm{C}$, the temperature difference under $5^{\circ} \mathrm{C}$, and a good temperature distribution. The possibility to curve and bend the pipes makes them suitable in almost any battery design, realizing unique and efficient cooling systems. Figure 2 shows a scheme of a heat-pipe-based BTMS, equipped with a further U-pipe system (remote heat transfer heat pipe system, RHE-HP) which helps in transporting heat away.

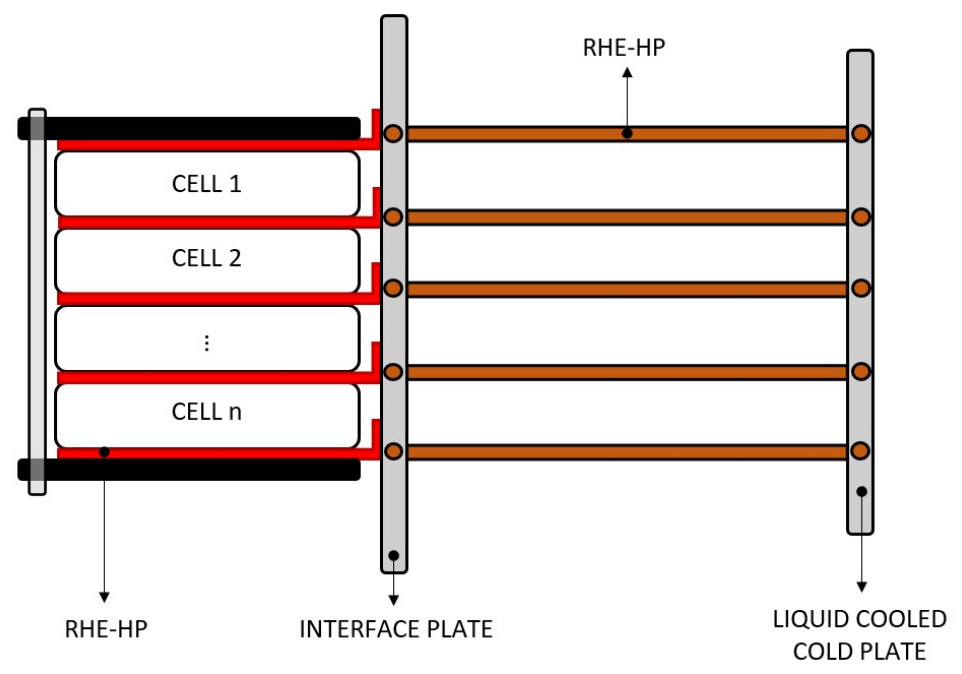

Figure 2. Schene of a heat pipe-based BTMS assembly equipped with a RHE-HP system, as studied in [52].

The interface plate connects the heat pipe cooling plates system (HPCP) and the RHE$\mathrm{HP}$ one. Several types of research have been carried on studying the influence of many factors on the efficiency of HP systems. For their experiments, Putra et al. [37] use different coolants and modify the heat flux load studying the maximum temperature and the best system performance. The coolants chosen are distilled water, alcohol $96 \%$, and acetone $95 \%$ with a filling ratio of $60 \%$. Looking at the evaporator temperatures during the transient case, it is shown that they increase quickly followed by a drop. This is due to super-heating, which occurs when the boiling point is reached. As the heat flux load increases, the duration of the transient decreases. Another factor that influences the transient is the capacitance of 
the system, which is a function of the mass of the system itself. For all the evaporator and condenser temperatures, the shortest transients are obtained with acetone and alcohol as coolants. During the steady-state case, the same temperature distribution can be seen for distilled water and alcohol, except when the highest heat flux load is reached: in that case, alcohol and acetone have an equal temperature distribution. The evaporator temperature is always under $50{ }^{\circ} \mathrm{C}$ for all the heat flux loads and almost all the coolants. The lowest temperature difference between the evaporator and the condenser is obtained with acetone in all the experiments carried out. Another consideration is that as the heat flux load increases, at the beginning, it is possible to see the alcohol evaporator temperature close to the distilled water one and then closer to the acetone one. This is because a rise in heat flux load is followed by a pressure increase, which is the cause of higher temperatures. Depending on the coolant, the evaporator temperature will be different. It has been found that, for the highest heat flux load, the acetone condenser temperature is very different from the other coolant ones: this is due to super-heating in the evaporator and for the vapor infiltration with a consequent increasing of the liquid temperature and much more heat transported towards the condenser. However, the lowest temperature difference is obtained with acetone for the most moderate heat flux load. The best performance is reached using acetone as a coolant and with the highest heat flux load. Wang et al. [53] studied cylindrical cells' battery performances, taking into account the effect of several structural parameters such as the spacing, the thickness of the conductive elements, and the angle between the battery and the conductive elements. Simulations show that the height of the conductive element is the parameter that most influences the temperature distribution. Moreover, the angle is a second influencing factor, while the thickness of the conductive element and the spacing have a minimum effect.

\subsubsection{Immersive Solutions}

This method helps to make the performance of the heat pipes system more efficient. Adopted by Tesla, it puts about $25 \%$ of the cell lateral surface in direct contact with the cold plate, with the cooling liquid circulating inside. The liquid circulates in metal thin pipes embedded in an extruded compound with the function of the thermal interface layer and electric insulation between the cells and the cooling medium. The remaining internal volume among cells is filled by a thermal interface that is constituted by intumescent gel, which is not electrically conductive. This material coats the sidewall of the cell casing, which is not in contact with the cold plate, and the space at both cell sides between the terminal and the metal connection plate.

\subsection{Innovative Cooling Strategies}

Among the different cooling systems, the most common ones are the air-based and the liquid-based BTMSs. Innovative studies brought to new promising cooling systems (carbon-fiber-based phase change materials, hybrid cooling systems) which, however, are not yet as widespread due to high costs.

\section{Phase Change Materials}

Phase change materials (PCMs) are materials that change their physical state, from solid to liquid and vice versa, to store and release heat. A solid-phase PCM starts absorbing heat from the battery and, at a certain temperature (it depends on the specific PCM), the melting begins. As the PCM absorbs heat, the battery is maintained to a target temperature. When the PCM is cooled by the environmental changes, the phase changes to solid again, releasing energy in the form of latent heat. There are around 200 different PCMs that can target temperatures between $-50^{\circ} \mathrm{C}$ and $150{ }^{\circ} \mathrm{C}$ [54]. For electric vehicle BTMSs, it should be necessary to test PCMs in a smaller temperature range, but the starting costs are still high. This is one of the reasons why PCMs are not as common in BTMSs. On the other hand, PCMs are shown to be one of the most efficient coolants thanks to their high heat storage capacity. The operating costs are quite low, and the retention of properties in sequential 
cycles is a very appreciable characteristic [55]. There are several kinds of PCMs, different in their composition and for the temperatures at which they change their phase. The most used are water-based PCMs, salt hydrates, paraffin, or innovative and eco-friendly plant-based PCMs. There are also innovative methods to improve PCMs' characteristics such as loading them with composite materials and metal foams. Samimi et al. studied innovative PCM loaded with carbon fiber [56] to increase the PCMs' thermal diffusivity (which is usually low) and, consequently, improving the temperature uniformity in the battery cells. Carbon-based materials have been chosen as proper conductive fillers because of their excellent thermal and electrical properties, their chemical stability, and their lower density than metals. For the experiments, different cooling media (air, wax as unloaded PCM, carbon-fiber-loaded PCM) have been compared during the discharge of a lithium-ion battery, provide evidence for the results of the research. It is shown that the higher the percentage of carbon fiber loading is, the lower the resulting cell temperature is. Then, PCMs not only act like heat sinks but, if loaded with carbon fiber, also lead to a better temperature distribution in the cells thanks to their improved thermal conductivity.

\subsection{Hybrid Cooling Systems}

Some hybrid BTMSs combine natural air convection with liquid and thermoelectric cooling systems [45]. With a thermoelectric cooler (TEC), all the processes concern transformations from electricity to heat and vice versa. These systems can work like coolers as well as like heaters (useful for those technologies that have to work in the extremely lowtemperature environment). Lyu et al. compare the temperature reached by a cylindrical lithium-ion cell if it is cooled with air, with liquid, and finally with a hybrid BTMS, which combines air and liquid cooling methods and a TEC system. Results show that during the test with air-cooling, the cell temperature increases with the voltage, and the higher is it, the faster the temperature rising. With the liquid-cooling, it is shown that the cell temperature and the water temperature rise almost together and with a more moderate trend. Lower cell temperatures can be obtained using the hybrid TEC system.

\subsection{Fire-Prevention Strategies}

The incredible spread of lithium-ion battery packs seen in recent years is easily understandable if we think about their specific capacity, energy density, and power density. All these characteristics are higher in Li-ion batteries rather than in the outdated batteries, but this new technology leads to some issues. One of the hardest challenges in the use of lithium-ion batteries is to find valid methods to prevent or face the so-called thermal runaway. It is a dangerous phenomenon during which the temperature rises and exothermic reactions are triggered, and these could lead to fires or explosions. There may be several causes that generate the thermal runaway: short circuits, battery overcharging, and design and manufacturing defects [49].

\subsubsection{Methods to Prevent Thermal Runaway}

There are several ways of acting against the thermal runaway and these can be divided into three categories, taking into account the effects on the process. The first category regards preventive measures, such as the addition of flame retardants. The second category involves fail-safe measures that stop or decrease the damage caused by thermal runaway, such as separators or cell venting techniques. The third category concerns actions for extinguishing fires once the thermal runaway has occurred [49]. There is another classification about the way to prevent thermal runaway or reduce its damages. Three main ways of acting corresponding to three levels of protection have been identified: cell-to-cell, module-to-module, and battery pack level.

- Cell-to-cell. This is the highest level of protection using engineered materials between every single cell. Obviously, if we consider space constraints, this represents a challenge but the advantages are relevant: in case of thermal runaway, the material surrounding the cells absorbs heat and minimize the propagation of thermal 
effects to the adjacent cells [47]. Thanks to their heat-absorbing nature, phase-change materials (PCMs) are often used in cell-to-cell protection. Moreover, if they change phase from liquid to gas, they also bring with them the cell gases out from the battery modules. The shape of the cells has to be taken into account because it influences the PCM that it is possible to use. For cylindrical cells, the PCM can be solid; it is not the same for pouch batteries that need liquid phase material as they expand and contract continuously.

- Module-to-module. This kind of protection follows the same philosophy of the cellto-cell one, but it separates the modules one from the other. This is a lower level of protection with respect to the previous one but it is lighter and easily fittable on several kinds of batteries.

- Battery pack. This represents the lowest level of protection because it does not work against the heat propagation between the cells or between the modules, but it only gives more time to the car occupants to put themselves in safe.

\subsubsection{Emergency Spray Cooling}

There are some emergency situations during which rapid battery pack cooling is required. With a common BTMS, it is usually hard to deal with these events with the right timing. An efficient solution for these issues is adding a supplemental refrigerant spray cooling system [48], not only useful to let the temperature drop fast but also to suppress oxygen, one of the possible causes of the exothermic reaction. When the thermal sensors detect an incoming thermal runaway, the refrigerant is sprayed inside the battery box, and it gasifies due to the high temperature strengthening the heat convection. In this way, a rapid temperature decrease occurs and the generated refrigerant gasses push the oxygen out of the box. Vents positioned in the right places can also contribute to the oxygen flow out. Several tests have been carried on about different spray modes: continuous, fixedinterval intermittent, and non-fixed-interval intermittent mode. With the continuous mode, the result is the most efficient cooling method and the maximum value of temperature difference uniformity. On the other hand, oxygen suppression is not better than the one obtained with the intermittent modes. With intermittent modes, the higher is the frequency of the spray, the better is the efficiency of the cooling. Concerning the temperature difference uniformity, the non-fixed-interval intermittent mode is less influenced by the spray frequency than the fixed-interval intermittent one. Another advantage of the intermittent modes is that using them it is easier to maintain the low-oxygen status.

\section{CFD Analysis of a Hybrid Solution}

The battery arrangement studied in this section is a hybrid solution with staggered cylindrical cells embedded in solid support and cooled by a fluid that flows in wavy channels. This study is part of a deep investigation of the performances of battery packs conducted by our research group in the automotive field, with dedicated experimental campaigns in which the theoretical results shown in this work are deployed and validated in the laboratory. The novelty of this solution is the strict coupling of solid plastic matrix and channels for liquid cooling [57]. The geometry of a portion of the hybrid solution is shown in Figure 3.

In the figure, the gray part is the solid plastic support with the function to fix the cells, and the blue zones are the wavy channels where the coolant flows. This study aims to optimize the distance $p$ between two cells and the width $c$ of the channels. Twelve combinations of $p$ and $c$ have been chosen for the optimization, shown in Table 2. 

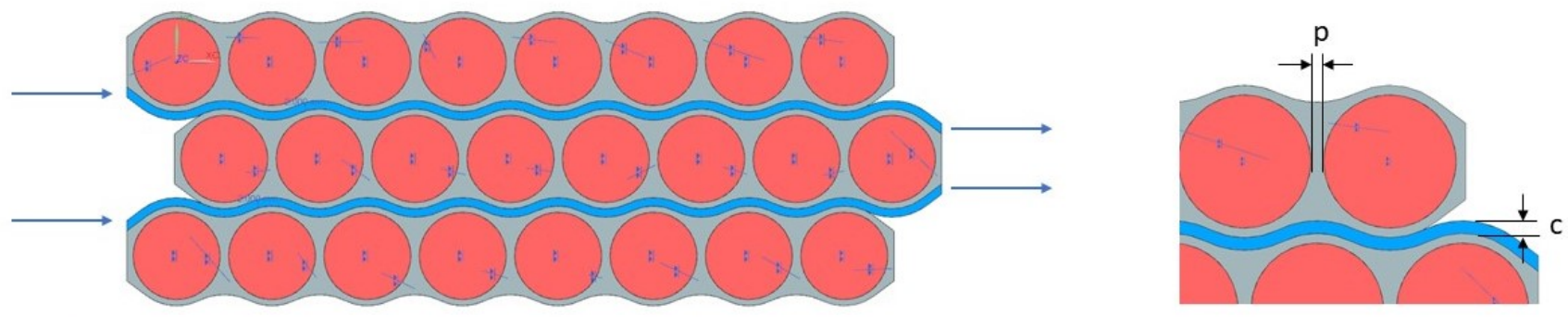

Figure 3. Section of a portion of the battery arrangement (left) and a zoomed-in image of the sketch (right).

Table 2. Parameters chosen for the optimization of the parameters $p$ and $c$.

\begin{tabular}{ccc}
\hline Geometry Number & $p(\mathbf{m m})$ & $c(\mathbf{m m})$ \\
\hline 1 & 1 & 1 \\
2 & 1 & 2 \\
3 & 1 & 3 \\
4 & 2 & 1 \\
5 & 2 & 2 \\
6 & 2 & 3 \\
7 & 3 & 1 \\
8 & 3 & 2 \\
9 & 3 & 3 \\
10 & 1 & 5 \\
11 & 2 & 5 \\
12 & 3 & 5
\end{tabular}

A representative part of the battery pack has been chosen for the simulations, as shown in Figure 4, with two lines of cells cut in their symmetry plane, with the channel between the two lines.

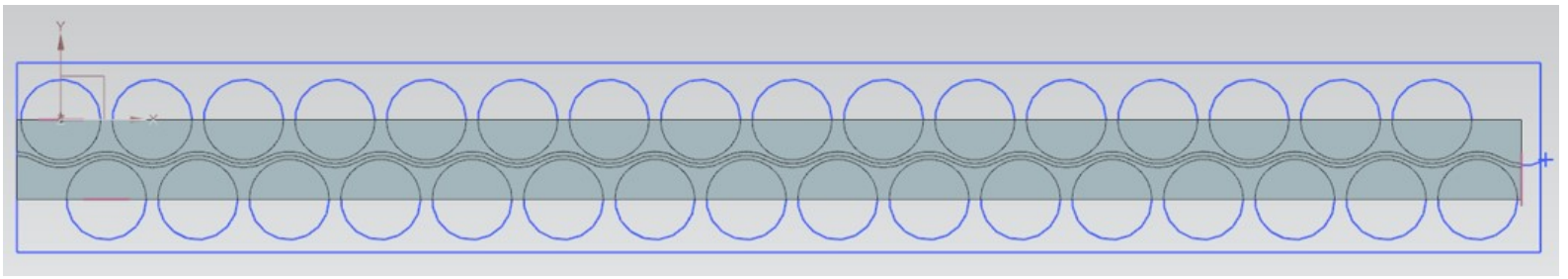

Figure 4. Fundamental unit analyzed in the simulations.

The real geometry of the battery is obtained by repeating periodically this part in the direction perpendicular to the flow. The number of cells in the direction parallel to the coolant flow was varied from 8 to 16 to show the linear behavior of the cell temperature as a function of the distance from the coolant inlet. In the present paper, the cells have a format 21,700 , but the approach can be easily up-scaled to cells with a different format. The Li-ion cells are considered as made by homogeneous material with density $2680 \mathrm{~kg} / \mathrm{m}^{3}$, thermal conductivity $3.4 \mathrm{~W} /(\mathrm{m} \mathrm{K})$, and heat capacity $1280 \mathrm{~J} /(\mathrm{kg} \mathrm{K})$. Two materials are compared for the cell support, a common plastic with thermal conductivity $k_{1}=0.28 \mathrm{~W} /(\mathrm{m} \mathrm{K})$ and density $1380 \mathrm{~kg} / \mathrm{m}^{3}$ (here called "plastic 1 "), and a conductive plastic with additives with thermal conductivity $k_{2}=1 \mathrm{~W} /(\mathrm{m} \mathrm{K})$ and density $1450 \mathrm{~kg} / \mathrm{m}^{3}$ (here called "plastic 2"). The two materials have specific heat $1100 \mathrm{~J} /(\mathrm{kg} \mathrm{K})$. These values refer to plastic material that are used in our laboratory to realize the support for the cell in the battery pack. The CFD code STAR-CCM+ has been employed to solve the steady-state Reynolds-averaged 
Navier-Stokes (RANS) equations with realizable $k-\varepsilon$ turbulence model. Bidimensional meshes with polygonal elements have been created for each configuration, as shown in Figure 5.

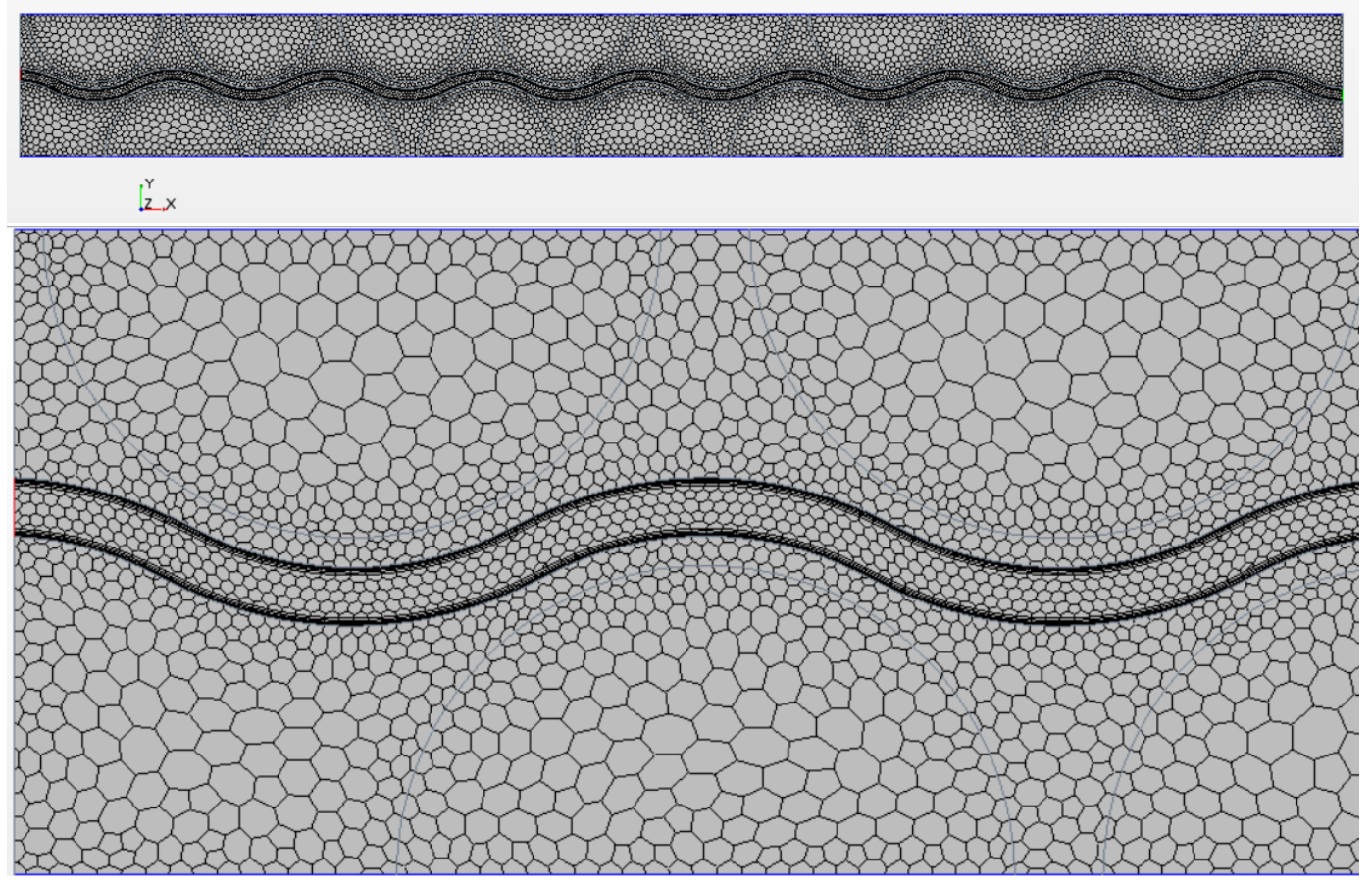

Figure 5. Mesh of a portion of the battery arrangement (top) and zoom of the mesh refinement and prism layer (bottom).

A base size of $0.8 \mathrm{~mm}$ and a surface grow rate of 1.3 have been set for each mesh. Once the target surface size is defined, a mesh refinement is necessary to concentrate spacial resolution in the fluid flow zone. The mesh in the fluid zone mesh has a finer resolution with a base size of $0.5 \mathrm{~mm}$ in order to get at least 10 elements along the channel height. In addition, a boundary layer has been modeled in the fluid zone with five layers with a total thickness of $33 \%$ of the base size, as shown in Figure 5. The final mesh has 14,939 cells. The studied cases are steady-state problems for incompressible flows, with conjugate heat transfer. The equations that describe this problem are the incompressible Navier-Stokes equations, together with the energy conduction for the solid region and convection equations for the fluid region. The continuity equation, together with the momentum balance equation, were solved for the liquid phase:

$$
\frac{\partial u_{i}}{\partial t}+u_{j} \frac{\partial u_{i}}{\partial x_{j}}=-\frac{1}{\rho} \frac{\partial p}{\partial x_{i}}+v\left[\nabla^{2} u_{i}+\frac{1}{3} \vec{\nabla}(\vec{\nabla} \cdot \vec{u})\right]
$$

The energy equation in temperature formulation has been solved for the flow region:

$$
\frac{\partial T}{\partial t}+u_{i} \frac{\partial T}{\partial x_{j}}=\alpha \nabla^{2} T+\frac{q_{g}}{\rho c}+\frac{v}{\rho c} \Phi
$$

where $\alpha=\frac{k}{\rho c}$ is the fluid thermal diffusivity and $\Psi=v \phi$ is called the Dissipation Function and is defined as $\nu \phi=D_{i j} \tau_{i j}$. The governing equation for the solid is

$$
k \frac{\partial^{2} T}{\partial x_{i}^{2}}=0
$$

where $k$ is the fluid thermal conductivity and $c$ is the specific heat. The temperature at the interface between the solid and liquid region is equal, while the heat flux entering 
one region at one side of the interface is equal to the flux leaving the other region on the other side of the interface. A heat source is defined at the center of each cell so that the temperature of the system rises according to the governing equations and the materials ${ }^{\prime}$ properties. Contact interface conditions are applied at interfaces between solid and fluid regions. Additionally, a thermal contact resistance of $0.001921 \mathrm{~W} / \mathrm{m}^{2} \mathrm{~K}$ is considered between the plastic support and the cells for mechanical backlash. In all the cases, the inlet fluid has a temperature of $20^{\circ} \mathrm{C}$. The cases of air-cooling and water-cooling have been considered in order to evidence the main strengths and challenges related to the two approaches. Different cooling-fluid velocity ranges have been considered in the two cases in order to have similar pressure drop ranges along the channels. A steady thermal power $Q=4 \mathrm{~W}$ has been assigned to each cell, because these values were measured in our laboratory for some extreme automotive regimes [57].

\subsection{Air-Cooling}

In the first case the cooling fluid is air. The inlet velocities considered in this case are $v=13.9 \mathrm{~m} / \mathrm{s}, v=27.8 \mathrm{~m} / \mathrm{s}$, and $v=38.9 \mathrm{~m} / \mathrm{s}$, which correspond to the Reynolds number is in the range $(900-13,000)$. The characteristic length for the Reynolds number is the channel width $c$. The maximum temperature of the cells obtained for the case of plastic 1 with air-cooling are summarized in Figure 6.

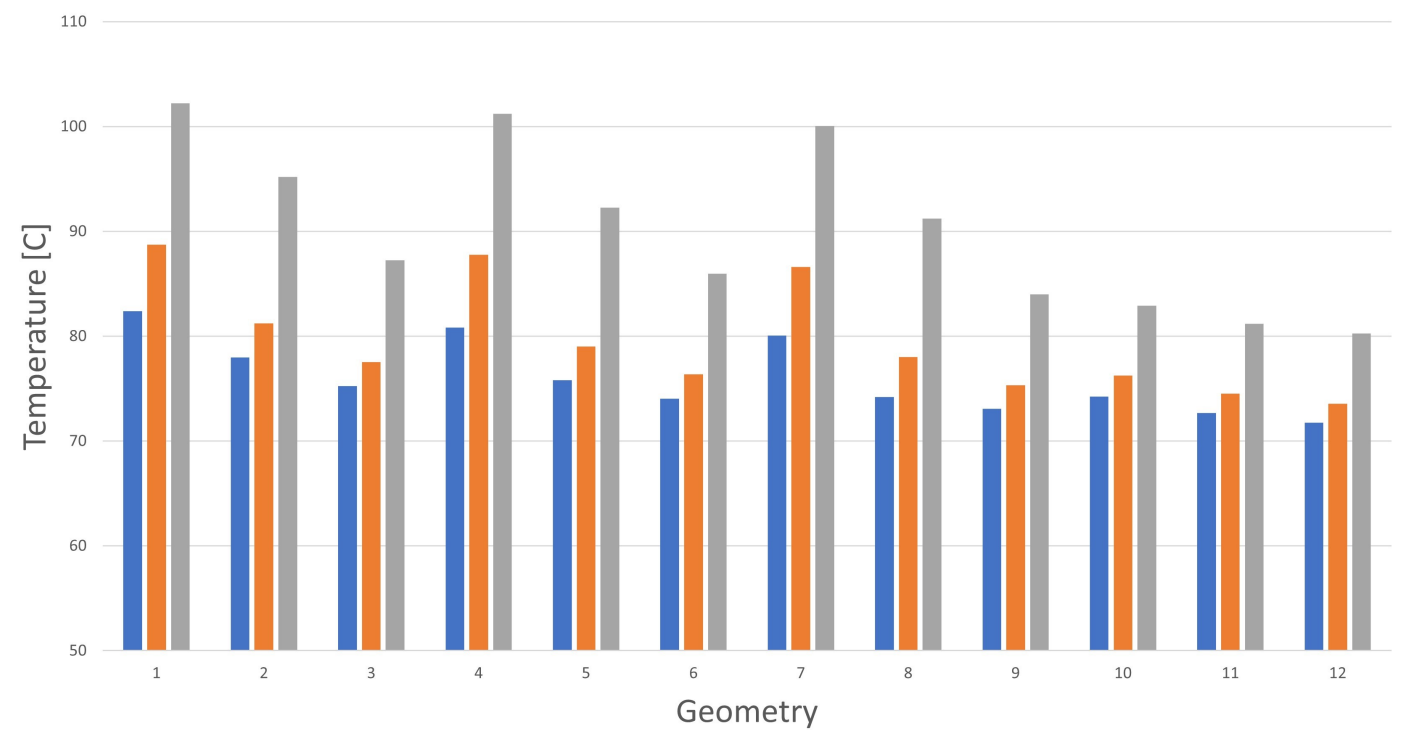

Figure 6. Maximum temperature of the cells obtained for the case of plastic 1 and air as a cooling fluid. Inlet velocities are $v=13.9 \mathrm{~m} / \mathrm{s}$ (grey), $v=27.8 \mathrm{~m} / \mathrm{s}$ (orange), and $v=38.9 \mathrm{~m} / \mathrm{s}$ (blue).

The figure shows that the maximum temperature of the cells decreases as the air velocity increases. Moreover, the maximum temperature of the cells decreases as the channel width $c$ increases, while its dependence on the axial distance between the cells is weak. The best geometry is $\mathrm{n}$. 12, with $c=5 \mathrm{~mm}$ and $p=3 \mathrm{~mm}$. These results can be compared with the maximum temperatures on the cells obtained for the case with plastic 2 , as shown in Figure 7.

Figures 6 and 7 show similar trends, but the values of the maximum temperatures obtained with plastic 2 are about $10^{\circ} \mathrm{C}$ lower than those obtained with plastic 1 . The best geometry with air-cooling is again the $\mathrm{n} .12$ for low velocities $(v=13.9 \mathrm{~m} / \mathrm{s}$ or $v=27.8 \mathrm{~m} / \mathrm{s})$, while for high velocities $(v=38.9 \mathrm{~m} / \mathrm{s})$ the geometry with $c=3 \mathrm{~mm}$ and $p=2 \mathrm{~mm}$ is the one which gives the lowest maximum temperature of the cells. The temperature distribution on the cells and in the channel, obtained for the geometry $n$. 12 , is shown by Figure 8 for the case of plastic 1 . 


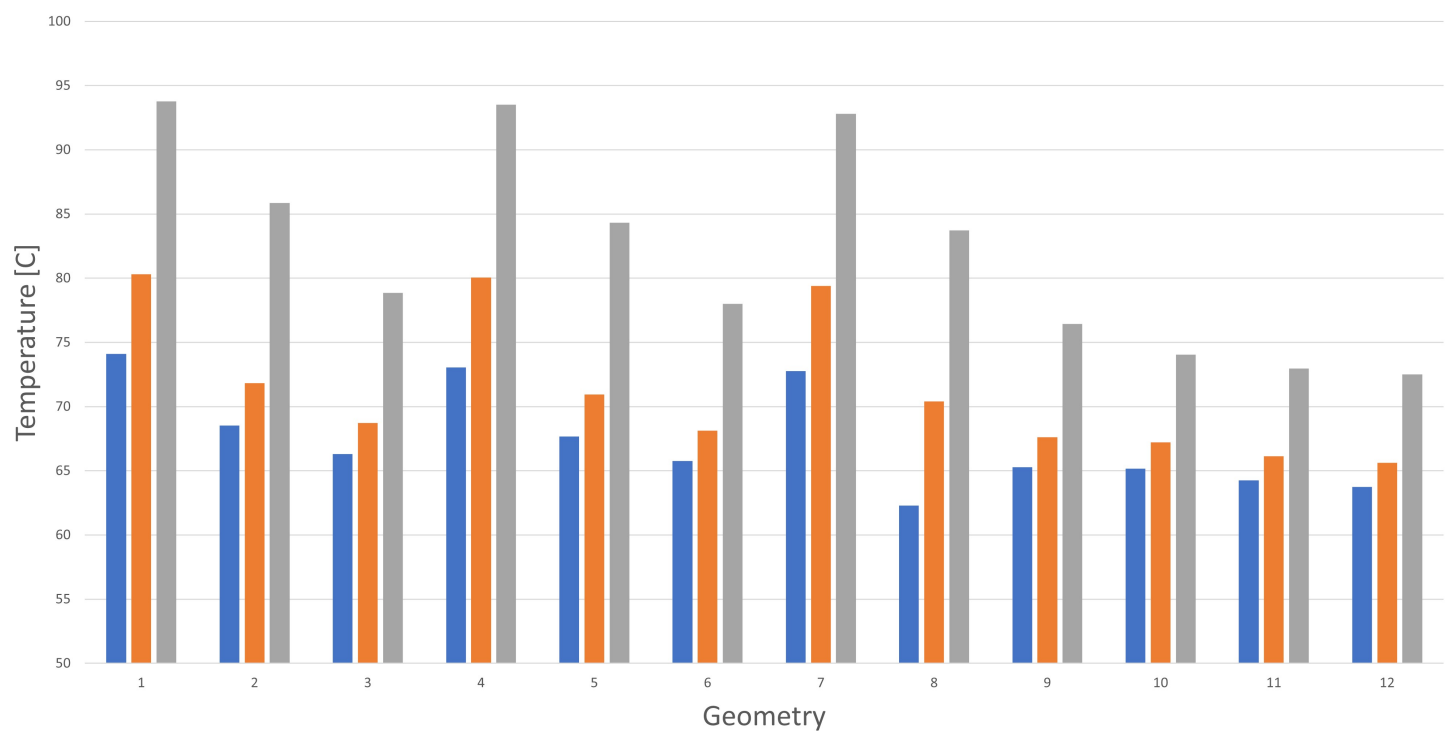

Figure 7. Maximum temperature of the cells obtained for the case of plastic 2 and air as a cooling fluid. Inlet velocities are $v=13.9 \mathrm{~m} / \mathrm{s}$ (grey), $v=27.8 \mathrm{~m} / \mathrm{s}$ (orange), and $v=38.9 \mathrm{~m} / \mathrm{s}$ (blue).
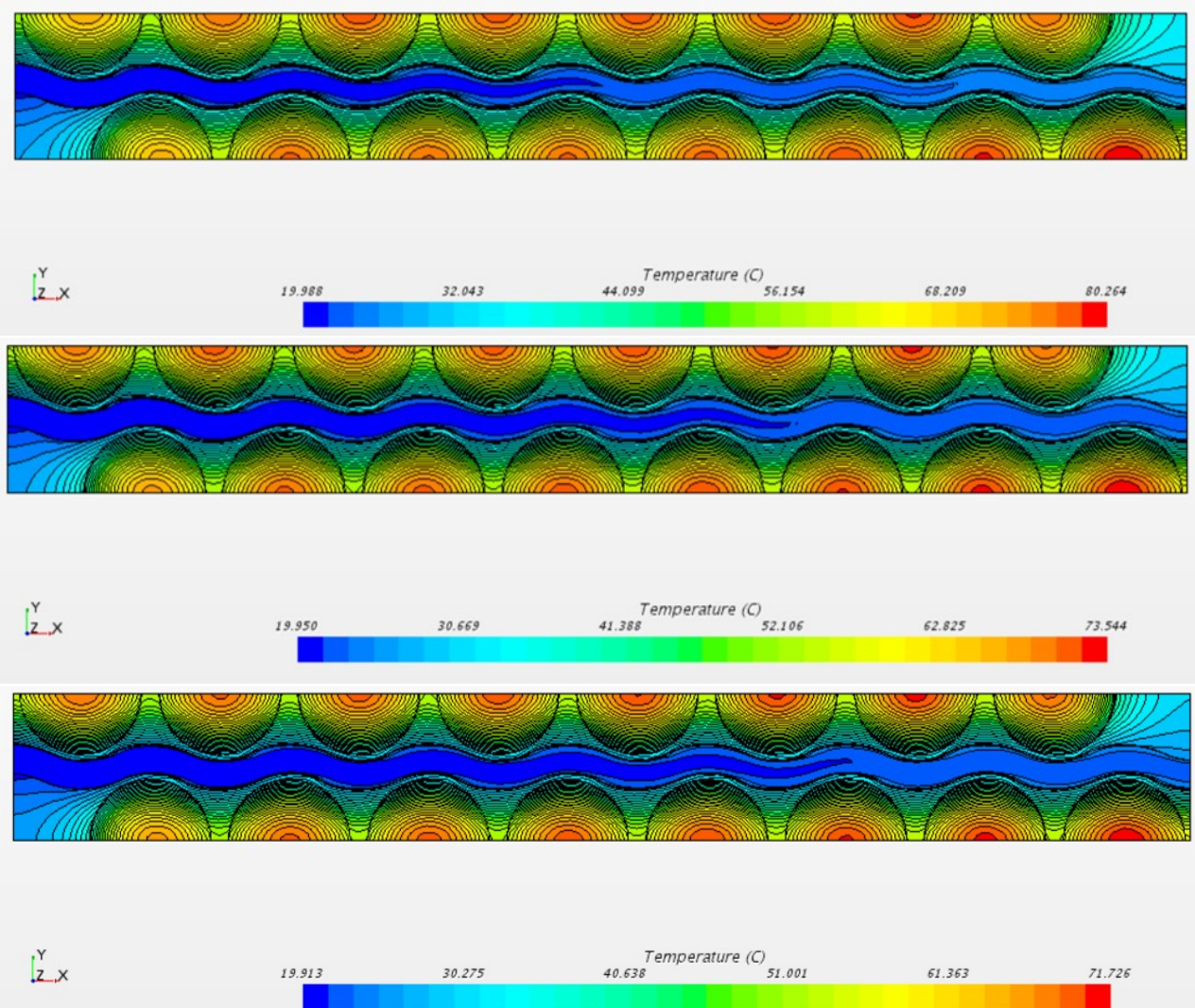

Figure 8. Temperature of the cells obtained for the case of geometry n. 12 and air as cooling fluid. Inlet velocities are $v=13.9 \mathrm{~m} / \mathrm{s}$ (top), $v=27.8 \mathrm{~m} / \mathrm{s}$ (middle), and $v=38.9 \mathrm{~m} / \mathrm{s}$ (bottom).

The figure shows that the maximum temperature difference between the first and the last cell is $9^{\circ} \mathrm{C}$ for the case with $v=13.9 \mathrm{~m} / \mathrm{s}$, while it is $6{ }^{\circ} \mathrm{C}$ for the case with $v=27.8 \mathrm{~m} / \mathrm{s}$ and $5{ }^{\circ} \mathrm{C}$ for the case with $v=38.9 \mathrm{~m} / \mathrm{s}$. The number of cells along the direction of the flow has been varied from 8 to 16 to show that the cell temperature is a linear function of the cell number. Figure 9 shows the cell temperature as a function of the cell number obtained for geometry n. 12 . 


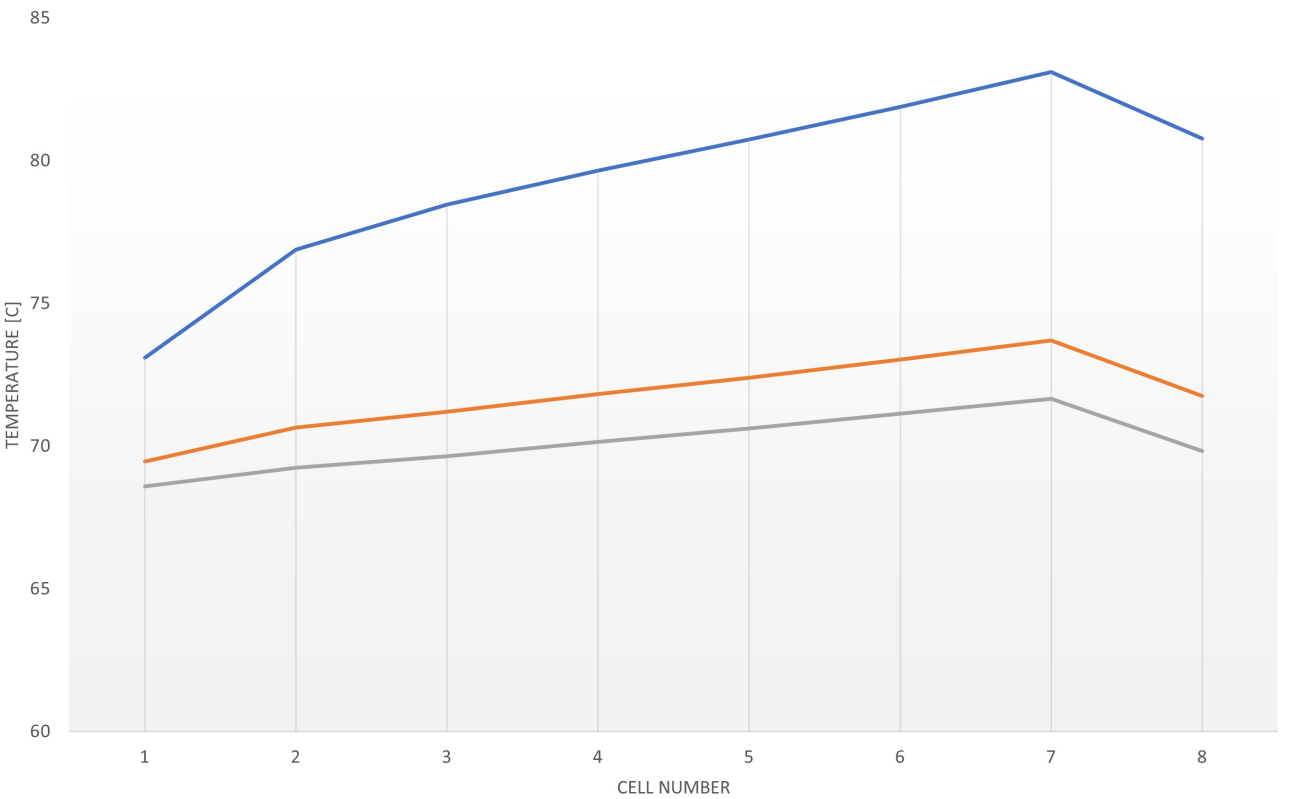

Figure 9. Temperature of the cells as a function of the cell number, obtained for the case of geometry n. 12 , and air as cooling fluid. Inlet velocities are $v=13.9 \mathrm{~m} / \mathrm{s}$ (blue line), $v=27.8 \mathrm{~m} / \mathrm{s}$ (red line), and $v=38.9 \mathrm{~m} / \mathrm{s}$ (grey line).

The slope of the central part of the curves shown in Figure 9 is a crucial parameter for the battery design, which has to be minimized to find the optimal parameters. For the case of air-cooling, the results of the simulations can be summarized as follows:

- The maximum temperature of the cells decreases weakly as the axial distance between the cells, and it strongly decreases with the channel width,

- The temperature of the cells linearly increases with the number of the cells in the direction of the flow, and the trend is a function of the air-flow velocity within the channels,

- $\quad$ By changing the solid material in which the cells are embedded, one obtains similar trends with lower absolute values of the temperature distribution as the thermal conductivity increases.

\subsection{Water-Cooling}

In the second case the cooling fluid is water. The inlet velocities considered in this case are $v=0.1 \mathrm{~m} / \mathrm{s}$ and $v=1 \mathrm{~m} / \mathrm{s}$; i.e., the Reynolds number is in the range $(100 \div 6000)$. The characteristic length in the Reynolds number is the channel width $c$. The results for the case of plastic 1 with water cooling are summarized in Figure 10.

The figure shows that the maximum temperature of the cells increases as the channel width $c$ increases and decreases as the axial distance $p$ between the cells increases. The best geometry is $\mathrm{n}$. 7, with $p=3 \mathrm{~mm}$ and $c=1 \mathrm{~mm}$. These results can be compared with the results obtained with plastic 2 with the same geometry, as summarized in Figure 11.

The Figures 10 and 11 show similar trends but the values of the maximum temperature are about $6-7^{\circ} \mathrm{C}$ lower with the plastic 2 . The best geometry with water cooling is the n. 7 , i.e., the one with the smallest channel. The temperature difference on the cells for the geometry n. 7 is shown by Figure 12 for the case of plastic 1. 


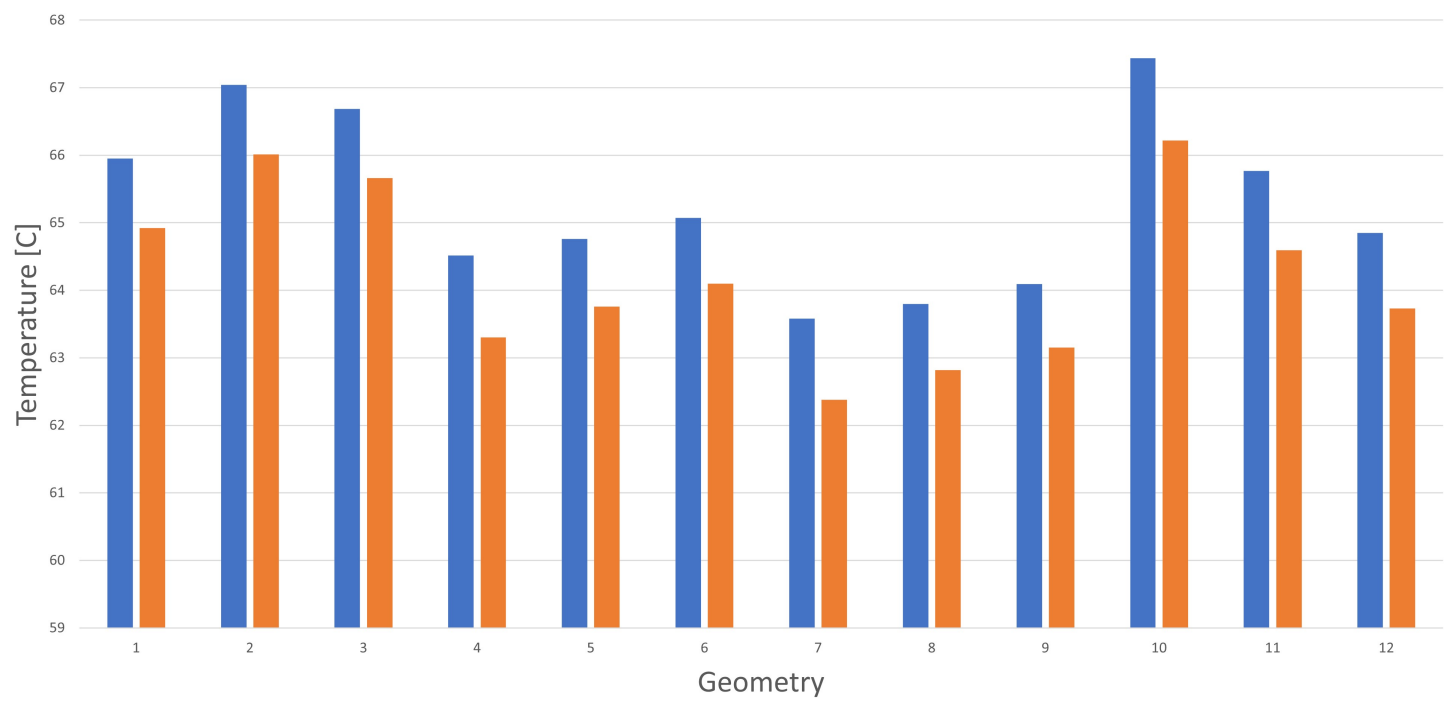

Figure 10. Maximum temperature of the cells obtained for the case of plastic 1 and water as a cooling fluid. Inlet velocities are $v=0.1 \mathrm{~m} / \mathrm{s}$ (blue) and $v=1 \mathrm{~m} / \mathrm{s}$ (orange).

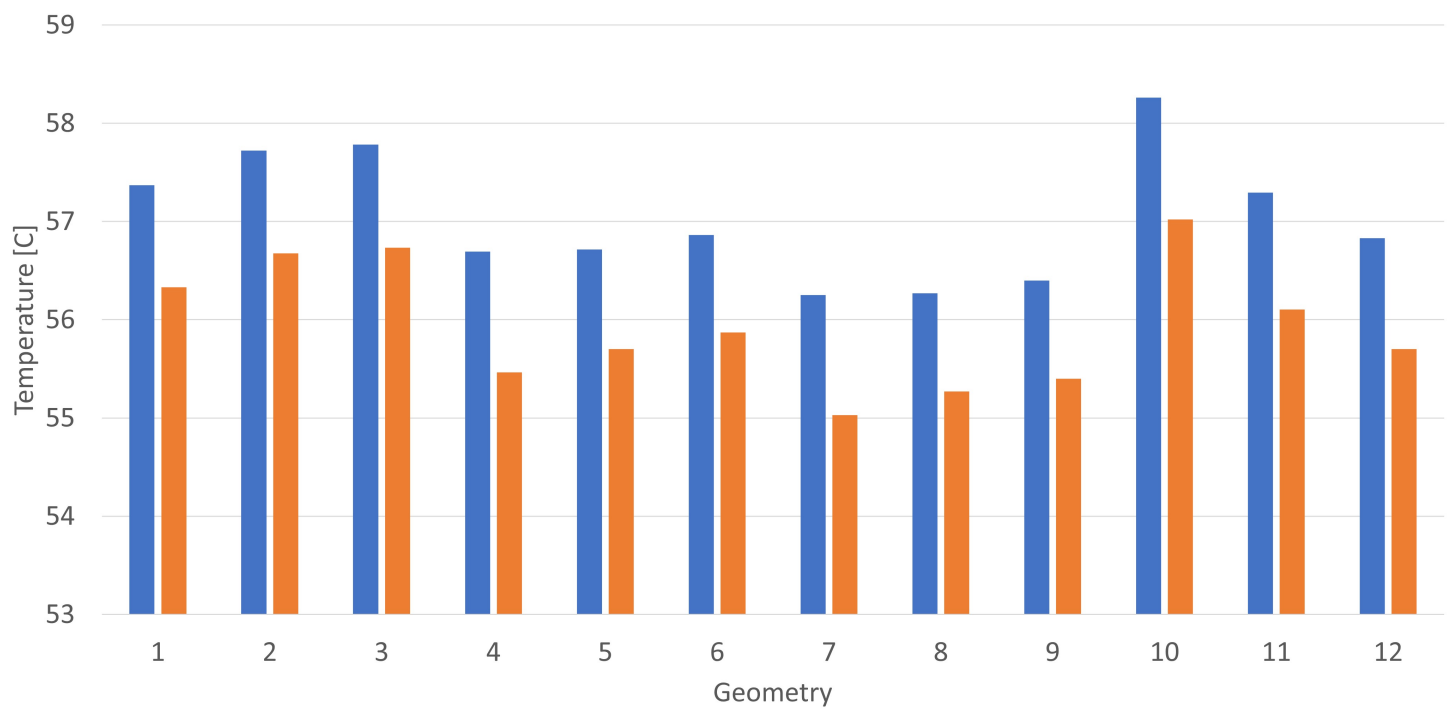

Figure 11. Maximum temperature of the cells obtained for the case of plastic 2 and water as a cooling fluid. Inlet velocities are $v=0.1 \mathrm{~m} / \mathrm{s}$ (blue) and $v=1 \mathrm{~m} / \mathrm{s}$ (orange).

The figure shows that the maximum temperature difference between the first and the last cell is $4{ }^{\circ} \mathrm{C}$ for the case with $v=0.1 \mathrm{~m} / \mathrm{s}$, and it is $2{ }^{\circ} \mathrm{C}$ for the case with $v=1 \mathrm{~m} / \mathrm{s}$. The number of cells along the direction of the flow has been varied from 8 to 16 to show that the cell temperature is a linear function of the cell number. Figure 13 shows the cell temperature as a function of the cell number obtained for a channel width $c=1 \mathrm{~mm}$. The inlet velocity is $v=0.1 \mathrm{~m} / \mathrm{s}$.

The slope of the central part of the curves shown in Figure 13 is a crucial parameter for the battery design, which has to be minimized to find the optimal parameters. For the case of water-cooling, the results of the simulations can be summarized as follows:

- The maximum temperature of the cells decreases as the axial distance between the cells, and it increases with the channel width;

- The temperature of the cells linearly increases with the number of the cells in the direction of the flow, and the trend is a function of the water-flow velocity within the channels and of the axial distance between the cells; 
- By changing the solid material in which the cells are embedded, one obtain similar trends with lower absolute values of the temperature distribution as the thermal conductivity increases.

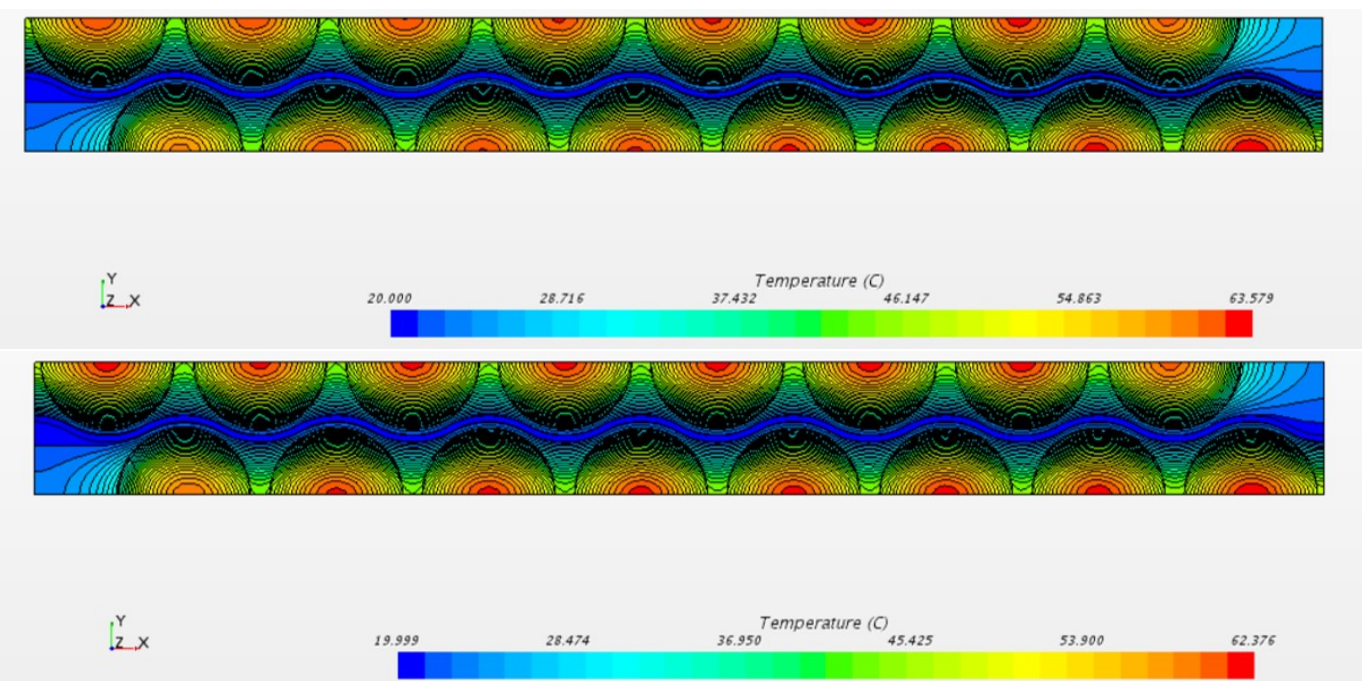

Figure 12. Temperature of the cells obtained for the case of geometry n. 7 and water as cooling fluid. Inlet velocities are $v=0.1 \mathrm{~m} / \mathrm{s}$ (top) and $v=1 \mathrm{~m} / \mathrm{s}$ (bottom).

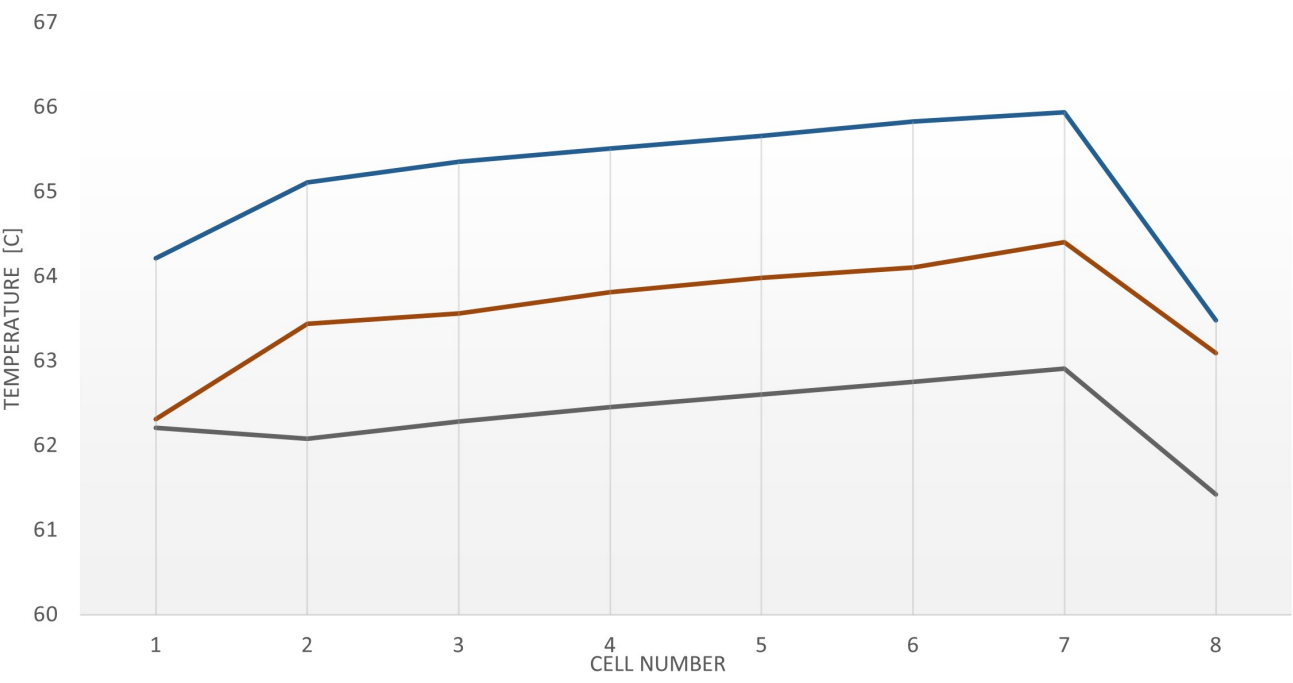

Figure 13. Temperature of the cells as a function of the cell number, obtained for the case of channel width $c=1 \mathrm{~mm}$ and water as cooling fluid. The distances between the cells are $p=1 \mathrm{~mm}$ (blue line), $p=2 \mathrm{~mm}$ (red line) and $p=3 \mathrm{~mm}$ (grey line).

\section{Conclusions}

A survey of the existent thermal management systems for lithium batteries has been presented, showing, in particular, some air-cooling and liquid-cooling approaches. The benefits resulting with the installation of a baffle plate and the importance of the design of the cell arrangements' structures have been shown. In this context, a hybrid system that combines heat conduction between cells in the longitudinal direction and forced convection in channels between the cells lines is presented. This approach is studied numerically using a CFD approach. It is shown that a combination between cooling fluid, solid material that connects the cells, and distances between the cells leads to the determination of the optimal thermal management arrangement. This means that the lowest temperature of 
the cells and the lowest temperature differences within the battery are obtained by this methodology. The best dimensions of the channels with air-cooling and water-cooling are discussed, showing that with air-cooling the best choice is to increase the width of the channel, while with water-cooling, the best choice is to reduce it. A linear temperature increase in the cells along the direction of the flow is found, and the dependence on the solid matrix thermal conductivity is found. These results show that a multi-parameter optimization approach gives the best arrangement in terms of number of cells and their packing density, as a function of the thermal characteristics of the solid matrix where the cells are embedded.

Author Contributions: Data curation, M.F., E.P.B.D.V., A.H. and B.P.; methodology, A.H. and B.P.; investigation, M.F., E.P.B.D.V.; validation, E.P.B.D.V.; formal analysis, A.H., C.R. and B.P.; writingoriginal draft, M.F. and B.P.; supervision, B.P.; funding acquisition, B.P. All authors have read and agreed to the published version of the manuscript.

Funding: This research was fund by Emilia-Romagna Region, under the PORFESR program, years 2018-2019, thanks to the LiBER project.

Institutional Review Board Statement: Not applicable.

Informed Consent Statement: Not applicable.

Data Availability Statement: Not applicable.

Acknowledgments: The authors would also like to thank Tommaso Brugo, Luca Frigerio and Andrea Bitto from the Department of Industrial Engineering, University of Bologna, for their support in the CAD design of the brick geometries analyzed.

Conflicts of Interest: The authors declare no conflict of interest.

\section{References}

1. Liu, H.; Wei, Z.; He, W.; Zhao, J. Thermal issues about Li-ion batteries and recent progress in battery thermal management systems: A review. Energy Convers. Manag. 2017, 150, 304-330. [CrossRef]

2. Kim, J.; Oh, J.; Lee, H. Review on battery thermal management system for electric vehicles. Appl. Therm. Eng. 2019, 149, 192-212. [CrossRef]

3. Lowe, M.; Tokuoka, S.; Trigg, T.; Gereffi, G. Lithium-ion Batteries for Electric Vehicles: The U.S. Value Chain; Center on Globalization, Governance and Competitiveness; Duke University: Durham, NC, USA. 2010.

4. Bolsinger, C.; Birke, K.P. Effect of different cooling configurations on thermal gradients inside cylindrical battery cells. J. Energy Storage 2019, 21, 222-230. [CrossRef]

5. An, Z.; Shah, K.; Jia, L.; Ma, Y. Modeling and analysis of thermal runaway in Li-ion cell. Appl. Therm. Eng. 2019, 160, 113960. [CrossRef]

6. Berdichevsky, G. Kelty, K.; Straubel, J.B.; Toomre, E. The Tesla Roadster Battery System; Testa Motors: Palo Alto, CA, USA, 2006.

7. Opitz, A.; Badami, P.; Shen, L.; Vignarooban, K.; Kannan, A.M. Can Li-Ion batteries be the panacea for automotive applications? Renew. Sustain. Energy Rev. 2017, 68, 685-692. [CrossRef]

8. Huang, Y.; Lu, Y.; Huang, R.; Chen, J.; Chen, F.; Liu, Z.; Yu, X.; Roskilly, A.P. Study on the thermal interaction and heat dissipation of cylindrical Lithium-Ion Battery cells. Energy Procedia 2017, 142, 4029-4036. [CrossRef]

9. Erb, D.; Kumar, S.; Carlson, E.; Ehrenberg, I.; Sarma, S. Analytical methods for determining the effects of lithium-ion cell size in aligned air-cooled battery packs. J. Energy Storage 2017, 10, 39-47. [CrossRef]

10. Wang, T.; Tseng, K.; Zhao, J.; Wei, Z. Thermal investigation of lithium-ion battery module with different cell arrangement structures and forced air-cooling strategies. Appl. Energy 2014, 134, 229-238. [CrossRef]

11. Lu, Z.; Yu, X.; Wei, L.; Qiu, Y.; Zhang, L.; Meng, X.; Jin, L. Parametric study of forced air cooling strategy for lithium-ion battery pack with staggered arrangement. Appl. Therm. Eng. 2018, 136, 28-40. [CrossRef]

12. Subramanian, M.; Hoang, A.T.; Kalidasan, B.; Nižetić, S.; Solomon, J.M.; Balasubramanian, D.C.S.; Metghalchi, H.; Nguyen, X.P. A technical review on composite phase change material based secondary assisted battery thermal management system for electric vehicles. J. Clean. Prod. 2021, 322, 129079. [CrossRef]

13. Sharma, D.K.; Prabhakar, A. A review on air cooled and air centric hybrid thermal management techniques for Li-ion battery packs in electric vehicles. J. Energy Storage 2021, 41, 102885. [CrossRef]

14. Wang, Q.; Jiang, B.; Li, B.; Yan, Y. A critical review of thermal management models and solutions of lithium-ion batteries for the development of pure electric vehicles. Renew. Sustain. Energy Rev. 2016, 64, 106-128. [CrossRef]

15. Sato, N. Thermal behavior analysis of lithium-ion batteries for electric and hybrid vehicles. J. Power Sources 2001, 99, 70-77. [CrossRef] 
16. Zhou, H.; Zhou, F.; Xu, L.; Kong, J.; Yang, Q. Thermal performance of cylindrical Lithium-ion battery thermal management system based on air distribution pipe. Int. J. Heat Mass Transf. 2019, 131, 984-998. [CrossRef]

17. Zhang, S.S.; Xu, K.X.; Jow, T.R. The low temperature performance of Li-ion batteries. J. Power Sources 2003, 225, 137-140. [CrossRef]

18. Shabani, B.; Biju, M. Theoretical Modelling Methods for Thermal Management of Batteries. Energies 2015, 8, 10153-10177. [CrossRef]

19. Moghaddam, H.; Mazyar, S. Designing Battery Thermal Management Systems (BTMS) for Cylindrical Lithium-Ion Battery Modules Using CFD; KTH School of Industrial Engineering and Management: Stockholm, Sweden, 2019.

20. Wu, W.; Wang, S.; Wu, W.; Chen, K.; Hong, S.; Lai, Y. A critical review of battery thermal performance and liquid based battery thermal management. Energy Convers. Manag. 2019, 182, 262-281. [CrossRef]

21. Jiang, J.; Ruan, H.; Sun, B.; Wang, L.; Gao, W.; Zhang, W. A low-temperature internal heating strategy without lifetime reduction for large-size automotive lithium-ion battery pack. Appl. Energy 2018, 230, 257-266. [CrossRef]

22. Xu, X.; He, R. Research on the heat dissipation performance of battery pack based on forced air cooling. J. Power Sources 2013, 240, 33-41. [CrossRef]

23. Zhao, G.; Wang, X.; Negnevitsky, M.; Zhang, H. A review of air-cooling battery thermal management systems for electric and hybrid electric vehicles. J. Power Sources 2021, 501, 230001. [CrossRef]

24. Xie, J.; Ge, Z.; Zang, M.; Wang, S. Structural optimization of lithium-ion battery pack with forced air cooling system. Appl. Therm. Eng. 2017, 126, 583-593. [CrossRef]

25. Fan, Y.; Zhan, D.; Tan, X.; Lyu, P.; Rao, J. Optimization of cooling strategies for an electric vehicle in high-temperature environment. Appl. Therm. Eng. 2021, 195, 117088. [CrossRef]

26. E, J.; Yue, M.; Chen, J.; Zhu, H.; Deng, Y.; Zhu, Y.; Zhang, F.; Wen, M.; Zhang, B.; Kang, S. Effects of the different air cooling strategies on cooling performance of a lithium-ion battery module with baffle. Appl. Therm. Eng. 2018, 144, 231-241. [CrossRef]

27. Chen, K.; Wang, S.; Song, M.; Chen, L. Configuration optimization of battery pack in parallel air-cooled battery thermal management system using an optimization strategy. Appl. Therm. Eng. 2017, 123, 177-186. [CrossRef]

28. Hong, S.; Zhang, X.; Chen, K.; Wang, S. Design of flow configuration for parallel air-cooled battery thermal management system with secondary vent. Int. J. Heat Mass Transf. 2018, 116, 1204-1212. [CrossRef]

29. Shahid, S.; Agelin-Chaab, M. Experimental and numerical studies on air cooling and temperature uniformity in a battery pack. Int. J. Energy Res. 2018, 42, 2246-2262. [CrossRef]

30. Yang, T.; Yang, N.; Zhang, X.; Li, G. Investigation of the thermal performance of axial-flow air cooling for the lithium-ion battery pack. Int. J. Therm. Sci. 2016, 108, 132-144. [CrossRef]

31. Sefidan, A.M.; Sojoudi, S.; Saha, S.C. Nanofluid-based cooling of cylindrical lithium-ion battery packs employing forced air flow. Int. J. Therm. Sci. 2017, 177, 44-58. [CrossRef]

32. Jarrett, A.; Kim, I.Y. Design optimization of electric vehicle battery cooling plates for thermal performance. J. Power Sources 2011, 196, 10359-10368. [CrossRef]

33. Jarrett, A.; Kim, I.Y. Influence of operating conditions on the optimum design of electric vehicle battery cooling plates. J. Power Sources 2014, 245, 644-655. [CrossRef]

34. Darcovich, K.; MacNeil, D.D.; Recoskie, S.; Cadic, Q.; Ilinca, F.; Kenney, B. Coupled Numerical Approach for Automotive Battery Pack Lifetime Estimates with Thermal Management. J. Electrochem. Energy Convers. Storage 2018, 15, 021004. [CrossRef]

35. Rao, Z.; Wang, S.; Wu, M.; Lin, Z.; Li, F. Experimental investigation on thermal management of electric vehicle battery with heat pipe. Energy Convers. Manag. 2013, 65, 92-97. [CrossRef]

36. Mbulu, H.; Laoonual, Y.; Wongwises, S. Experimental study on the thermal performance of a battery thermal management system using heat pipes. Case Stud. Therm. Eng. 2021, 26, 101029. [CrossRef]

37. Putra, N.; Ariantara, B.; Pamungkas, R.A. Experimental investigation on performance of lithium-ion battery thermal management system using flat plate loop heat pipe for electric vehicle application. Appl. Therm. Eng. 2016, 99, 784-789. [CrossRef]

38. Liang, L.; Zhao, Y.; Diao, Y.; Ren, R.; Jing, H. Inclined U-shaped flat microheat pipe array configuration for cooling and heating lithium-ion battery modules in electric vehicles. Energy 2021, 235, 121433. [CrossRef]

39. Zhou, Z.; Lv, Y.; Qu, J.; Sun, Q.; Grachev, D. Performance evaluation of hybrid oscillating heat pipe with carbon nanotube nanofluids for electric vehicle battery cooling. Appl. Therm. Eng. 2021, 196, 117300. [CrossRef]

40. Hong, S.H.; Jang, D.S.; Park, S.; Yun, S.; Kim, Y. Thermal performance of direct two-phase refrigerant cooling for lithium-ion batteries in electric vehicles. Appl. Therm. Eng. 2020, 173, 115213. [CrossRef]

41. Tang, X.; Guo, Q.; Li, M.; Wei, C.; Pan, Z.; Wang, Y. Performance analysis on liquid-cooled battery thermal management for electric vehicles based on machine learning. J. Power Sources 2021, 494, 229727. [CrossRef]

42. Al-Zareer, M.; Dincer, I.; Rosen, M.A. Performance assessment of a new hydrogen cooled prismatic battery pack arrangement for hydrogen hybrid electric vehicles. Energy Convers. Manag. 2018, 173, 303-319. [CrossRef]

43. Alipour, M.; Hassanpouryouzband, A.; Kizilel, R. Investigation of the Applicability of Helium-Based Cooling System for Li-Ion Batteries. Electrochem 2021, 2, 135-148. [CrossRef]

44. Al-Zareer, M.; Dincer, I.; Rosen, M.A. Electrochemical modeling and performance evaluation of a new ammonia-based battery thermal management system for electric and hybrid electric vehicles. Electrochim. Acta 2017, 247, 171-182. [CrossRef]

45. Lyu, Y.; Siddique, A.R.M.; Majid, S.H.; Biglarbegian, M.; Gadsden, S.A.; Mahmud, S. Electric vehicle battery thermal management system with thermoelectric cooling. Energy Rep. 2019, 5, 822-827. [CrossRef] 
46. Lyu, Y.; Siddique, A.R.M.; Gadsden, S.A.; Mahmud, S. Experimental investigation of thermoelectric cooling for a new battery pack design in a copper holder. Results Eng. 2021, 10, 100214. [CrossRef]

47. Liebscher, A. Preventing Thermal Runaway in Electric Vehicle Batteries. 2018. Available online: www.machinedesign.com/ materials/article/21837402/preventing-thermal-runaway-in-electric-vehicle-batteries (accessed on 1 December 2021).

48. Gao, Q.; Liu, Y.; Wang, G.; Deng, F.; Zhu, J. An experimental investigation of refrigerant emergency spray on cooling and oxygen suppression for overheating power battery. J. Power Sources 2019, 415, 33-43. [CrossRef]

49. Kong, L.; Li, C.; Jiang, J.; Pecht, M.G. Li-Ion Battery Fire Hazards and Safety Strategies. Energies 2018, 11, 2191. [CrossRef]

50. Darcovich, K.; MacNeil, D.; Recoskie, S.; Cadic, Q.; Ilinca, F. Comparison of cooling plate configurations for automotive battery pack thermal management. Appl. Therm. Eng. 2019, 155, 185-195. [CrossRef]

51. Deng, T.; Ran, Y.; Zhang, G.; Yin, Y. Novel leaf-like channels for cooling rectangular lithium ion batteries. Appl. Therm. Eng. 2019, 150, 1186-1196. [CrossRef]

52. Smith, J.; Singh, R.; Hinterberger, M.; Mochizuki, M. Battery thermal management system for electric vehicle using heat pipes. Int. J. Therm. Sci. 2018, 134, 517-529. [CrossRef]

53. Wang, J.; Gan, Y.; Liang, J.; Tan, M.; Li, Y. Sensitivity analysis of factors influencing a heat pipe-based thermal management system for a battery module with cylindrical cells. Appl. Therm. Eng. 2019, 151, 475-485. [CrossRef]

54. Sutterlin, W.R. A Phase Change Materials Comparison: Vegetable-Based vs. Paraffin-Based PCMs. 2015. Available online: www. chemicalonline.com/doc/a-phase-change-materials-comparison-vegetable-based-vs-paraffin-based-pcms-0001(accessed on 1 December 2021).

55. Babapoor, A.; Azizi, M.; Karimi, G. Thermal management of a Li-ion battery using carbon fiber-PCM composites. Appl. Therm. Eng. 2015, 85, 281-290. [CrossRef]

56. Samimi, F.; Babapoor, A.; Azizi, M.; Karimi, G. Thermal management analysis of a Li-ion battery cell using phase change material loaded with carbon fibers. Energy 2016, 96, 355-371. [CrossRef]

57. Rossi, C.; Pontara, D.; Falcomer, C.; Bertoldi, M. Simplified parameters estimation forthe dual polarization model of lithium-ion cell. In Lecture Notes in Electrical Engineering, Proceedings of the 13th International Conference of the IMACS TC1 Committee, Electrimacs 2019, Salerno, Italy, 21-23 May 2019; Springer: Berlin/Heidelberg, Germany, 2020; Volume 697, pp. 129-144. 